- denitrification processes are the physico-chemical parameters of the sorption material, the specific volume dentrification water, filtration rate and the ability and timeliness of regeneration, the minimum value for nitrogen-containing substances in the filter cycle and so on;

- demineralization vorotnavank method is material and selectivity of the membranes, adjusting the flow at permeate and concentrate in an automated manner, the flow rate of demineralized water, the use of regeneration and antiscalants, the need for blocks poperedni cleaning and the like;

- disinfection on the coefficient of efficiency, selectivity, specific output of disinfected water, prolonged duration of effect and the like;

- conditioning for optimal microcomponents cationic-anionic composition and to evaluate the effectiveness and homogeneity of the prepared water

- other stages of water treatment is the use of pumps, the influence of the material of the piping systems are available using membrane elements, and the like.

Identified dominant factors in water treatment contributes to obtaining treated water for the high stability of the finished product.

\title{
References:
}

1. Ivanov, S. V., Domaracki, V. A., Pribilski, V. L., etc. (2012). Innovative technology of fermentation products and wine-making: proc. (Ed. S. V. Ivanov). Kyiv, $487 \mathrm{p}$.

2. Kovalchuk, V. P. (2001). Of the comprehensive program of quality improvement of alcoholic beverages. Alcohol and tobacco, no 2, pp. 6-8.

\section{PRODUCTION OF FROZEN SEMI-FINISHED PRODUCT FOR A SMOOTHIE DRINK BASED STRAWBERRIES, DRIED APPLES AND OAT FLOCKS}

\section{Evgenia Sokolova ${ }^{1}$ \\ Larisa Tatar $^{2}$}

DOI: https://doi.org/10.30525/978-9934-588-11-2_15

A major role in strengthening health of people belongs to providing their full and healthy nutrition. A steady growth in the production of high-quality food products and beverages is required in order to accomplish this goal. Healthy nutrition is achieved by a balanced consumption of nourishing nutrients. The human body cannot receive a balanced diet that contains the entire set of essential substances because of the technological treatment of raw materials [1]. To ensure the proper and healthy diet, it is necessary to develop and create new products with high quality. Such products must to be balanced in their composition, as well as enriched with different

\footnotetext{
${ }^{1}$ Kharkiv State University of Food Technology and Trade, Ukraine

${ }^{2}$ Kharkiv State University of Food Technology and Trade, Ukraine 
functional properties [2]. When applying plant raw materials, there occurs the enrichment of products with natural nutrients, creating thereby the products with preventive and health-improving properties.

The utilization of Ukrainian plant raw materials and the implementation of developments related to new technologies in food production is a priority direction in the technology of food industry and public catering.

Refrigeration of fruit and berry semi-finished products makes it possible to obtain marketable products, which are sold to people, and then processed into drinks, juices, compotes, jams in the off-season period [3]. Freezing is one of the safest and most effective techniques for canning, which significantly slows down deterioration of food products. Freezing is based on a change in temperature below the cryoscopic, which terminates or suspends most physical, biochemical, and microbiological processes. Quick frozen fruits and berries are almost not inferior to fresh ones for their nutritional value and content of water-soluble vitamins [4].

Creation of alcohol-free drinks using vegetable raw materials - smoothies becomes more and more popular throughout the world. The choice of components for preparing a smoothie drink is rather wide. The recipe composition of the drink may include fresh, frozen, dried fruits, vegetables and berries, and also different spices, bran, groats, milk products. Depending on used components, smoothie may be both juice and a main dish or dessert.

Raw materials for making smoothies were selected that would own a large amount of vitamins and minerals. Strawberries contain many nutrients that condition their food and dietic value, including carbohydrates, represented by the high content of sugars (up to $12 \%$ ). The content of cellulose in strawberries is $4,0 \%$, proteins are near $1 \%$, that is a source of irreplaceable amino acids. Lipids are presented by saturated and unsaturated fatty acids. Strawberries contain many macro- and microelements, vitamins.

Dried apples have a rich chemical composition. Their high energetic value is conditioned by the increased quantity of carbohydrates (57,2\%). Dried apples have a rich vitamin composition - vitamin B4 $(17,6 \mathrm{mg})$ and vitamin $\mathrm{C}(3,9 \mathrm{~g})$. As to macroelements, dried fruits contain much potassium $(580 \mathrm{mg}$ ), phosphorus $(77 \mathrm{mg})$, magnesium (30 mg), calcium (111 $\mathrm{mg}$ ) and sodium $(87 \mathrm{mg})$, and also many microelements.

The chemical composition of oat flocks contain protein substances up to $12,5 \%$, fats up to $6 \%$, carbohydrates up to $66,5 \%$, ash up to $4,0 \%$, cellulose up to $12,2 \%$, water $12 \%$. Oat flocks exceed other groats by the amount of proteins $(13,1 \mathrm{~g})$, they contain all amino acids, irreplaceable for the organism. Their mineral and vitamin composition is presented by the wide assortment of substances, necessary for the human organism [5].

The use of a frozen semi-finished product for making a smoothie drink would make it possible to extent the assortment of frozen products, to reduce expenditures of labor and time for the preparation of drinks at home and in public catering [6]. The use of frozen semi-products at trade enterprises, hotel-restaurant business and everyday life favors the better organization of the staff work, economy of productive resources, decreasing time for cooking drinks. 


\section{References:}

1. Rickman, J. C., Bruhn, C. M., \& Barrett, D. M. (2007). Nutritional comparison of fresh, frozen, and canned fruits and vegetables II. Vitamin A and carotenoids, vitamin E, minerals and fiber. Journal of the Science of Food and Agriculture, 87(7), 1185-1196.

2. Walkling-Ribeiro, M., Noci, F., Cronin, D. A., Lyng, J. G., \& Morgan, D. J. (2010). Shelf life and sensory attributes of a fruit smoothie-type beverage processed with moderate heat and pulsed electric fields. LWT - Food Science and Technology, 43(7), 1067-1073.

3. Barbosa-Canovas, G. V., Altunakar, B., \& Mejia-Lorio, D. J. (2015). Freezing of Fruits and Vegetables: An Agribusiness Alternative for Rural and Semi-Rural Areas. Chapter 1. Food and Agriculture Organization of the United Nations. Rome.

4. Zhang, Y., Zhao, J.-H., Ding, Y., Xiao, H.-W., Sablani, S. S., Nie, Y. et. al. (2018). Changes in the vitamin $\mathrm{C}$ content of mango with water state and ice crystals under state/phase transitions during frozen storage. Journal of Food Engineering, 222, 49-53.

5. Odarchenko, D., Odarchenko, A., Sokolova, E., \& Mikhailik, V. (2018). Investigation of the influence of the process of freezing on microbiological factors of safety of frozen semi-product for cooking drink smoothie. EUREKA: Life Sciences, 2, 62-67.

6. Odarchenko, D., Odarchenko, A., Sokolova, E., \& Mikhailik, V. (2018). Cryoscopic and microbiological study of the semi-finished product for making a smoothie drink. Eastern-European Journal of Enterprise Technologies», seriya: Technology and equipment of food production, 2, $11(92), 65-70$.

\section{NECESSITY OF FILTRATION IN LIQUEUR-VODKAS PRODUCTION}

\section{Lesia Tarasiuk ${ }^{1}$ \\ Svitlana Oliynyk ${ }^{2}$}

DOI: https://doi.org/10.30525/978-9934-588-11-2_16

The constant development of the market requires the production of more qualitative alcoholic beverages with an increased resistance. Taking this requirement into account producers are looking for methods and means to improve the technology of production. Organoleptic parameters are the most important characteristics of the liqueur-vodkas products quality. While tasting study of products quality it is estimated appearance, taste and aroma, but of the most importance is beverage's transparency [1, p. 356].

For the filtration of alcohol-water mixtures and prepared products there are used such materials as quartz sand, garnet, mountain crystal, hydro-anthracite as well as some variants of linen, cotton, felt canvas, hushcloth, etc. [2, p. 6].

When creating recipes there are used such ingredients as skimmed milk powder, quail and chicken egg white, etc., which are coagulating substances that help to improve the organoleptic characteristics of sorting [2, p. 4].

\footnotetext{
${ }^{1}$ National University of Food Technology, Ukraine

${ }^{2}$ National University of Food Technology, Ukraine 